\title{
Assessment of the Effectiveness of External Control Institutions on Public Funds Management: Evidence from Ondo State Nigeria.
}

\author{
${ }^{1}$ Olurankinse felix pH.d, ${ }^{2}$ Bayo fatukasi pH.d \\ ${ }^{I}$ Department Of Accounting, Adekunle Ajasin University, Akungba - Akoko, Nigeria \\ ${ }^{2}$ Department Of Economics, Adekunle Ajasin University, Akungba - Akoko, Nigeria
}

\begin{abstract}
The paucity of funds in the government treasury today vis-avis the public tremendous demand for social and infrastructural facilities and the attendant problems of wide spread economic crimes such as corruption and fraudulent practices necessitated the establishment of external control institutions by the government as a way of suppressing the surge of mismanagement of funds in our public sectors. Despite the presence of these control institutions, the number of public officers engaging in corrupt acts and fraudulent practices is frequently on the increase. A pertinent question that readily comes to mind therefore is to what extent have these institutions been able to reduce these crimes? The study was carried out purposely to look into the activities of some of these institutions in order to determine their level of effectiveness. The study made use of well structured questionnaires designed on five points likert rating scale. Two hundred copies of questionnaires were administered to public officers drawn from the Ministries, Parastatals, Corporations and Agencies. One hundred and sixty six copies of the administered questionnaires were retrieved from the field survey. Data obtained from the questionnaires response were presented in tables and the analysis was done using descriptive and empirical tools. The descriptive analysis employs the use of tables, percentages and charts to describe the characteristics of the responses in the questionnaire. The empirical analyses employed the Censored Logistic regression of the Maximum likelihood technique to determine the relationship between effectiveness of external control and the three major factors. The result of the study shows that there is mismanagement of funds in our public sectors identified by fraud and corruption. Also, there is lack of accountability and transparency in managing public funds. The study recommends the need to strengthen Nigerian law enforcement and anti-corruption legislation to make external control independent of the executive. Also funding of these institutions should be autonomous and should be charged against the consolidated revenue fund.
\end{abstract}

Keywords: Public Fund, Control Institutions, Economic Crimes, Effectiveness, Accountability.

\section{Introduction}

Economic crimes as we witnessed today have become a tradition in every facet of our society and has eaten deeply into the fabric system of every Nigerian be it in the public or private sector. Despite the huge amount of funds allocated and released to government Ministries, Parastatals, Agencies and Corporations, the level of infrastructural decay is undoubtedly on the increase. As the year pass by, budgetary allocation to all these government departments keep increasing (incremental budgeting system) but without a corresponding increase in facilities on ground (social and infrastructural) for public consumption. There are wide spread record of facilities degradation and low level of standard of societal living. To this end, the federal government in its effort at checkmating and reducing the surge of these crimes, decided to establish some set of control institutions. These institutions are:

i. Independent corrupt practices commission (ICPC)

ii. Economic and financial crimes commission (EFCC)

iii. Public complaint commission (PAC)

iv. Due process and budget implementation (DPBI)

v. Human rights commission (HRC)

vi. Code of conduct bureau (CCB)

vii. Public account committee (PAC)

viii. Price intelligent and monitoring unit (PIMU)

The major functions of these institutions are to collectively monitor, control and engender due process, accountability and judicious spending of public funds. Nonetheless, these institutions have been criticised for poor performance judging by the increase wave of corruption and fraudulent practices pervading the public sector today. There are different school of thoughts and varying degree of discordant voices in regard to the poor performance of these institutions. Some school of thoughts are of the opinion that the institutions were 
established to antagonise and silent government critiques and oppositions. This is evidence in their selective and self styled prosecution of crime offenders. Besides, other school of thoughts believed that the institutions are like a toothless barking dog that can only bark but could not bite. They based their argument on the fact that they don't have the political will to prosecute 'some offenders' simply because they were not strengthening/ empowered legally enough. To worsen the situation and as a testimony, recently, the chairman of the EFCC lamented and cried out that the commission is incapacitated to pay their lawyers who are to prosecute crime offenders due to lack of funds. Reports in the dailies shows that a handful number of the culprits involving in corruption and fraudulent practices are prosecuted while majority did it with impunity. The PM news ( one of Nigerian news papers) of July $11^{\text {th }}, 2013$ reported that $84 \%$ of those surveyed by transparency international claimed that corruption had increased in the past two years, a higher percentage than almost any other country in the world. Troublingly, $75 \%$ of those surveyed also said the government was at the best, effective at fighting corruption worse than in all ten countries. The punch (one of Nigerian news) of $6^{\text {th }}$ September, 2013, reported that the 2012 transparent international corruption perception index placed Nigeria 135 out of 176 countries surveyed in the report. These therefore, have eroded the public mind and perception in believing that much can be achieved by these institutions.

\section{Genesis Of External Control Institutions}

Since the creation of modern public administration in Nigeria, there have been cases of official misuse of resources for personal enrichment. The country has seen its wealth withered with little to show in living conditions of the average human being. Corruption which has eaten deeply into our society has been identified to be the root cause of all societal crimes in Nigeria (Aransi, 2008). The pervasive corruption has been blamed on colonialism. According to this view, the nation's colonial history may have restricted any early influence in an ethical revolution. Throughout the colonial period, most Nigerians were stuck in ignorance and poverty. The trappings of flash cars, houses and success of the colonists may influence the poor to see the colonist as symbols of success and to emulate them in different political ways. Allegations of corruption against many top leaders are becoming more bizarre by the day. Petty corruption is reportedly widespread and surveys indicate that it is very hard to do business in Nigeria without having to pay facilitation payments to public officials. The transparency international 2012 perception index ranked Nigeria as $139^{\text {th }}$ out of 176 countries believed to be highly corrupt. The effort of the government at check meeting the menace of corruption in Nigeria brought about the establishment of some external control institutions.

The first among the external control institutions that was established is the independent corrupt practices commission (ICPC). It was inaugurated on the $29^{\text {th }}$ of September 2000 following the recommendation of President Olusegun Obasanjo. The mandate is to relieve and investigate reports of corruption and in an appropriate cases prosecute the offenders, to examine, review and enforce the correction of corruption prone systems and procedures of public bodies, with a view to eliminating corruption in public life and to educate and enlighten the public on and against corruption and related offences with a view to enlisting and fostering public support for the fight against corruption. The activities of the ICPC are governed by the corrupt practices and other related offences Act 2000.

In 2003, the Economic and Financial Crimes Commission (EFCC) was established as a law enforcement agency to investigate financial crimes while the ICPC targets corruption in the public sector especially bribery, gratification, graft and abuse or misuse of office, the EFCC investigates people in all sectors who appear to be living above their means and is empowered to investigate money laundering and other financial crimes.

\section{Corruption And Its Causes}

The word corruption is derived from a latin word "corruptus" which means to break or destroy. Literally, it means to break away or depart from morality, ethics and civics virtues. The World Bank defines corruption as the abuse of public office for private gains. Public office is abused for private gain when an official accepts, solicits or extorts a bribe. It is also abused when private agents actively offers bribes to circumvent public policies and processes for competitive advantage and profit. Public official is corrupt if he accepts money or money's worth for doing something that he is under a duty to do any way, that he is under a duty not to do or exercise a legitimate discretion for improper reasons (Otite,1986).

Microsoft Encarta Encyclopedia defines it as wrong doing by those in a special position of trust. Section 2 of the independent corrupt practices and other related offences commission Act 2000 defines corruption to include bribery, fraud and other related offences. The cause of corruption is multifarious but generally, corruption is caused by:

$>$ Greed

$>$ Lack of positive values

$>$ Porous system 
$>$ Weak enforcement and oversight mechanism

$>$ Excessive materialism

$>$ Societal pressure

$>$ Lack of virile welfare structures

$>$ Insecurity of employment tenure

$>$ Indiscipline

$>$ Inordinate desire for wealth accumulation

$>$ Poverty of the mind

$>$ Nepotism

$>$ Lack of genuine fear of God

\section{Evidences And Effects Of Corruption In Nigeria}

Corruption is the bane of Nigerian Socio Economic development, which threatens the existence of Nigeria as a political entity. The evidence of corruption is manifested in every sector of the economy. Shehu (2004) affirms that effects of corruption in the Nigerian society cannot be overemphasized. Corruption is indeed a cankerworm that has eaten deep into the fabric of Nigerian society. It is a monster that all and sundry blame for economic woes facing the country. Nearly every sphere of human endeavour is affected by corruption. And no profession is spared either. In 2012, the corruption perception indict ranked Nigeria 139 out of 176 countries acclaimed to be most corrupt. The PM news of July 11, 2013 rated Nigeria as the $8^{\text {th }}$ most corrupt nations. The 2013 Global Corruption Barometer which surveyed residents in 107 courtiers ranked Nigeria, Tamia Paraguay, Mexico as the largest countries on the globe with active corruption indices.

The widespread of corruption to every facet of Nigeria sector is with no exception to the religion circle. Tam David West, a professor and one time minister of petroleum asserts that he no longer go to church again because he sees a lot of corruption. He quoted a particular scenario where a staff of Sheraton Hotel stole millions of naira from his employer and donated same to a named church and the head of the church claimed the money was donated as tithe to the church and not to any individual. In the area of industry, adulteration has been a lingering issue. It spans through various industries, from fake petroleum products to fake fashion items, fake drugs, fake electronic gadgets, etc. all in the name of corruption.

Corruption Index In Nigeria Sector

Political parties

Police

National Assembly

Public officials and civil servants

Judiciary

Education

Military

Medical and health services

Non-governmental organizations (NGOs)

Religion bodies

Source: Transparency International, 2013.
94

$\%$

$\begin{array}{lll} & & 92 \\ 69 & & 73 \\ & & \\ & & 66 \\ & & 54 \\ & 45 & \\ & 33 & \\ 32 & & \\ & & \\ & & \end{array}$

66

54

Interestingly, successive governments pursued policies against corruption and it was the main reason why military made incursions into politics. Despite various policies adopted by governments, corruption is ever increasing in the country. Despite the establishment of control institutions, not much has been achieved in respect of the subject as allegations of corruption against many top leaders are becoming more bizarre by the day. One of the greatest weaknesses of these control institutions has been their lack of independence and susceptibility to political pressure. Noting that though Nigerian law provides criminal penalties for official corruption, government did not implement the law effectively and officials frequently engaged in corrupt practices with impurity. Akanbi (2005) affirmed that in the first three years of existence, the ICPC received a total of 942 petitions. In August 2003, about 400 of the petitions were under investigation and 60 were at various stages of prosecution. After the first four years, however, the ICPC had failed to make any major convictions. Akanbi blamed the lack of progress in part on severe underfunding. We also recalled the twists in the subsidy probe of June, 2012 "allegations and a video surfaced, allegedly showing Lawan accepting a 94.2 million naira $(\$ 605,000)$ bribe from entrepreneur Femi Otedola. Other evidenses include the stealing of 32.8 billion naira (\$210 million) police pension fund by a director of police pension office, Atiku Abubakar Kigo, criminal charge against former Governor of Bayelsa State, Timipre Sylva for laundering close to five billion naira (\$32 million) of funds belonging to state. Noting that the charges were instituted on February 24, 2012, and the court adjourned the trial till January 2013. The case of the former minister of works and housing, 
Hassan Lawal for money laundering and embezzlement of 75 billion naira ( $\$ 480$ million), the four governors allegedly misappropriated or stole 58 billion naira ( $\$ 115$ million) and Mr. Dimeji Bankole, former speaker of House of Representative and Deputy Speaker Usman Nafeda for the alleged misappropriation of one billion naira (\$6.4 million) and 40 billion naira ( $\$ 256$ million) respectively but which have recently been dismissed on the ground that EFCC had not brought a solid case against the duo. The latest issue of corruption is that of $\mathrm{N} 255 \mathrm{~m}$ worth of two BMW bullet proof cars allegedly purchased by the current aviation minister without budgetary approval. Several other causes which are too numerous to mention in this study are evidences of acute corruption in Nigeria.

\section{Ondo State In Perspective}

The evidence of corruption in ondo state in recent time is quite alarming and it cut across ministries, Parastaltals and local government settings. The guidance of march 20, 2013 reported a case of Ondo state oil producing area(OSOPADEC) chairman who was arrested over N61.63b fraud. It was reported that 13 exotic cars were driven from his house. The cars range from Toyota Tundra, Mercedes Benz R500, Toyota corolla, Two-door Toyota zolara, Toyota venza etc. The coment of June 8, 2012 report of ICPC arrest of an Akure South local government paymaster for misappropriation of funds, alleged diversion of millions of naira into personal accounts. On January 20, 2013 it was reported that the ICPC arrested the ondo state local government service commission chairman (name withheld). He was alleged to be using his position to institute a fraudulent syndicate by using his own local government as a focal point in the perpetuation of fraud. He was also accused of planting collaborators and stooges in the entire council treasury department across the state using them to effect inclusion of ghost workers in the payroll of the council with their salaries and entitlements diverted into private account of the chairman and his collaborators. He was also accused of amassing property worth over $\mathrm{N} 203 \mathrm{~m}$ naira including landed property, vehicles and a school from the proceeds of his fraudulent activities. The Nation of $19^{\text {th }}, 2011$ reported cases of some principals that were alleged of charging between N25,000 and $\mathrm{N} 50,000$ to indulge in West Africa examination malpractices. The commission which made the discovery through its National Anti-corruption Volunteer Corps (NAVC) claimed the practice was more noticeable in ondo state. He cited a case of a school where a male teacher impersonated a female student to write examination for the young girl. The sahara report of 2014, reported the arrest of deposed governor of ondo state in connection with massive allegation of corruption, abuse of office and theft of public funds. According to the reporter 'But just as we want to press with the storm of his arrest, sources told sahara reporters that the said governor has already been ordered released following instruction to the EFCC chairman from the presidency to do so immediately'. In summary, what we observe in Nigeria is that the citizens are sceptical about the outcome of the arrest of culprits as the EFCC is fond of arresting public officials for purpose of publicity or trial as none of the cases in which arrest were made and openly celebrated have made it to respectable trial.

\section{Effects Of Corruption}

$>$ It undermines the national image- a corruption ridden country stinks in the comity of nations and meaningful investments cannot be attracted nor developmental cooperation can be established because every Nigerian is viewed as corrupt and dubious outside. For instance, Nigeria has been consistently ranked among the most corrupt country in the world by Transparency International.

$>$ It threatens the very survival of a nation as it prevents the provision of basic social amenities for the citizenry. The money meant for development is often pocketed by a few thereby making good governance impossible. It has affected our health sectors not to talk of our educational institutions. As at today, not even one of the Universities in Nigeria is rated among the first 200 in the world and none is rated among the best in Africa. Corruption generally erodes standards to abysmal levels. Quality of goods and services cannot be guaranteed in a corrupt society.

$>$ Corruption aggravate unemployment and under development.

$>$ It engenders mass poverty and thwart efforts to overcome it.

$>$ Most infrastructural decay and unsatisfactory provision of amenities can be traced directly or indirectly to corruption. There is a total collapse of power and road net work in the country today due to corrupt attitude of past leaders.

$>$ It erodes the ethical base of society: -as due diligence, excellence, honesty, merit and integrity are discouraged.

$>$ It breeds all kinds of crimes and vandalism - arm robbery, kidnapping, youth agitation etc.

$>$ It lead to massive brain drain - a great number of Nigeria best brains have been driven to other part of the world where they now spearhead developmental and scientific exploits. 


\section{Data Analysis And Results}

The aim of this study is to investigate the effectiveness of external control institutions on public fund management in Ondo State of Nigeria. The research was a case study, survey design while the analysis follows the empirical causal design. Data were sourced from government workers of different affiliations in the State using a questionnaire. Four major public affiliations were sampled. These are Ministries, Parastatals, Corporations and Agencies. The design of the questionnaire follows the limited information dependent variable technique. That is the qualitative responses of respondents were quantified using the dichotomous variable method (Yes =1; No=0); and the polychotomous variable method - the Likert rating. That is

\begin{tabular}{|c|c|}
\hline Strongly Agree & $=5$ \\
\hline Agree & $=4$ \\
\hline $\begin{array}{l}\text { Disagree } \\
\text { Strongly Disagree }\end{array}$ & \\
\hline Undecided & $=$ \\
\hline
\end{tabular}

There are two sections in the questionnaire. Section A is the distribution of respondents by general characteristics. Section B is further subdivided into three sub-sections namely, response to presence of external control institutions. Six questions were raised to determine whether external control institutions are present and felt in the state. Responses to the operationalization (weak prosecution of economic crime, law enforcement etc) of such external control institutions. Five questions were raised to this regard. Responses to the effectiveness of external control and responses to the problem of fund management.

166 questionnaires were retrieved from the field survey. The analysis is divided into both descriptive and empirical analysis. The descriptive analysis employs the use of tables, percentages and charts to describe the characteristics of the responses in the questionnaire. The empirical analyses employed the Censored Logistic regression of the Maximum likelihood technique to determine the relationship between effectiveness of external control and the three major factors.

\section{Section A: Analysis of The Distribution Of Respondents}

Table 1: Distrbution Of Respondents By Sex
\begin{tabular}{|l|l|l|}
\hline & Frequency & Percentage \\
\hline Male & 101 & 60.8 \\
\hline Female & 65 & 39.2 \\
\hline Total & 166 & 100 \\
\hline
\end{tabular}

Figure 1: Column Bar Chart Showing Sex Distribution of Respondents

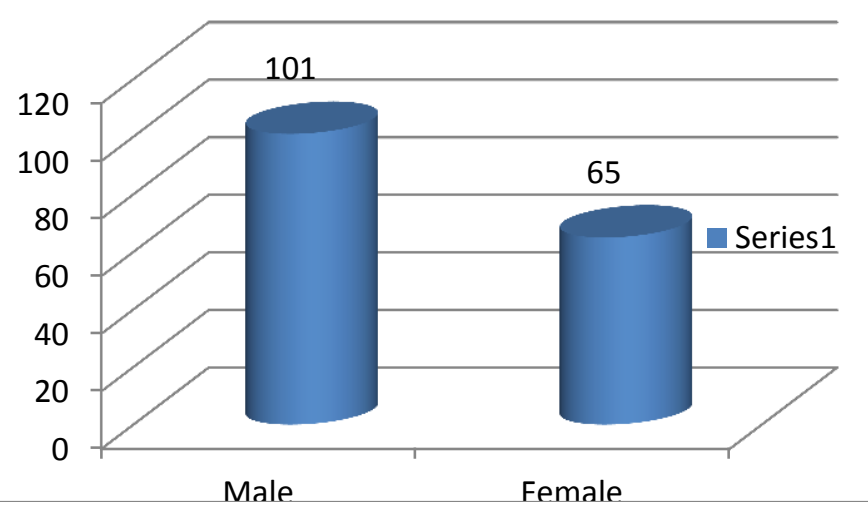

A look at Table 1 and Figure 1 shows that the majority of the respondents are male $(60.8 \%)$ while $39.2 \%$ are females.

Table 2: Distrbution Of Respondent By Age (In Years)

\begin{tabular}{|l|l|l|l|l|l|l|}
\hline & Below 20 & $\mathbf{2 1} \mathbf{- 3 0}$ & $\mathbf{3 1} \mathbf{- 4 0}$ & $\mathbf{4 1} \mathbf{- 5 0}$ & $\mathbf{5 0} \&$ above & Total \\
\hline Frequency & 0 & 14 & 63 & 65 & 20 & 162 \\
\hline Percentage & 0 & 8.6 & 38.9 & 40.1 & 12.3 & 100 \\
\hline
\end{tabular}

Table 2 and Figure 2 show that the majority of the respondents (40.1\%) belong to average ages of 41 to 50 years, $38.9 \%$ of the respondents are 31 to 40 years of age, $8.6 \%$ are 21 to 30 years of age while $12.3 \%$ of them are above 50 years. 


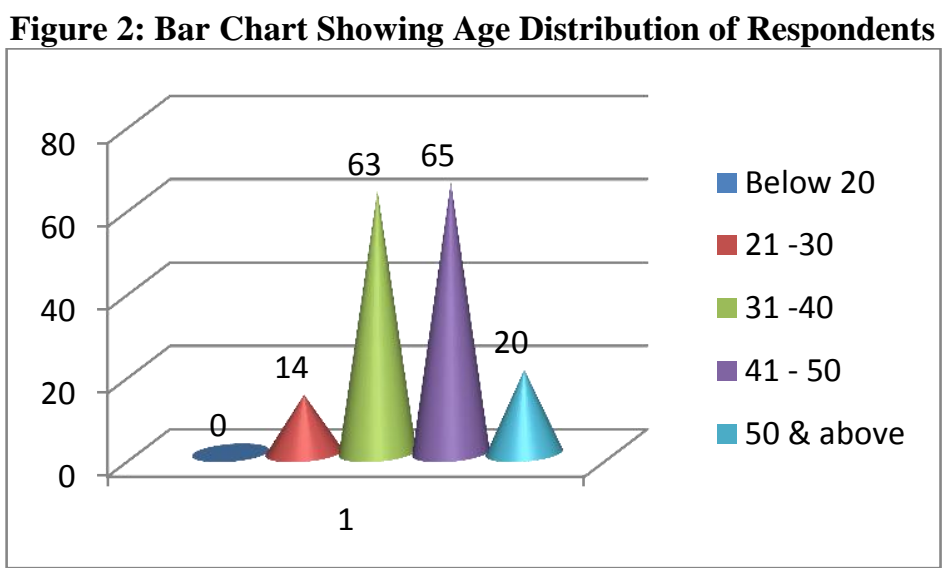

Table 3: Distribution Of Respondents By Educational Qualification

\begin{tabular}{|l|l|l|l|l|l|}
\hline Column1 & WASCE/SSCE & OND/NCE & BSc/HND & MSc/MBA & Total \\
\hline Frequncy & 5 & 31 & 104 & 19 & 159 \\
\hline Percentage & 3.1 & 19.5 & 65.4 & 11.9 & 100 \\
\hline
\end{tabular}

Table 3 and Figure 3 show the distribution of respondents by educational qualification. $65.4 \%$ of the respondents hold a BSc/HND certificate, $19.5 \%$ hold the OND/NCE certificate, $3.1 \%$ are secondary school leavers, while $11.9 \%$ hold higher certificates. Seven of the respondents did not respond to educational qualification question.

Figure 3: Bar Chart Showing Educational Qualification of Respondents

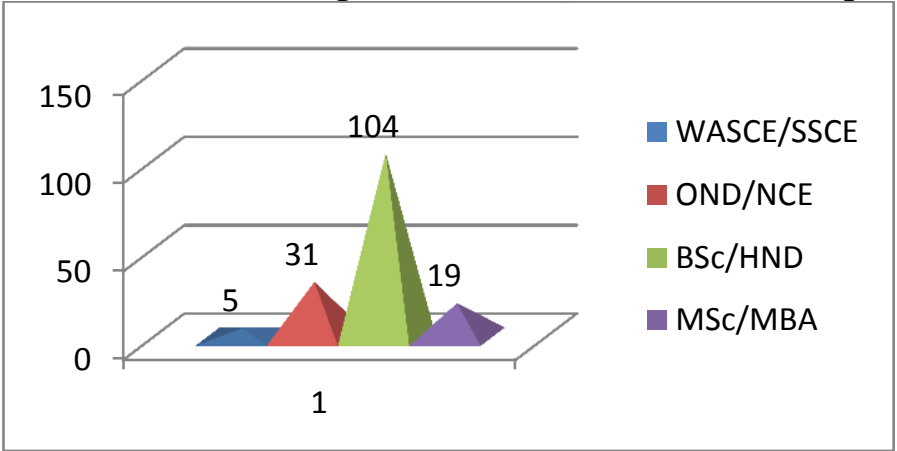

Table 4: Distribution Of Respondents By Affiliation

\begin{tabular}{|l|l|l|l|l|l|}
\hline Column1 & Ministry & Parastatals & Corporation & Agency & Column2 \\
\hline Frequency & 53 & 49 & 23 & 33 & 158 \\
\hline Percentage & 33.5 & 31.0 & 14.6 & 20.9 & \\
\hline
\end{tabular}

In Table 4 and Figure 4 it is clear that $(33.5 \%)$ of the respondents are Ministry workers. $31 \%$ work in various parastatals, $14.6 \%$ of the respondents belong to government corporations, while $20.9 \%$ belong to different Agencies. The respondents are evenly distributed by affiliation.

Figure 4: Bar Chart Showing Affiliations of Respondents

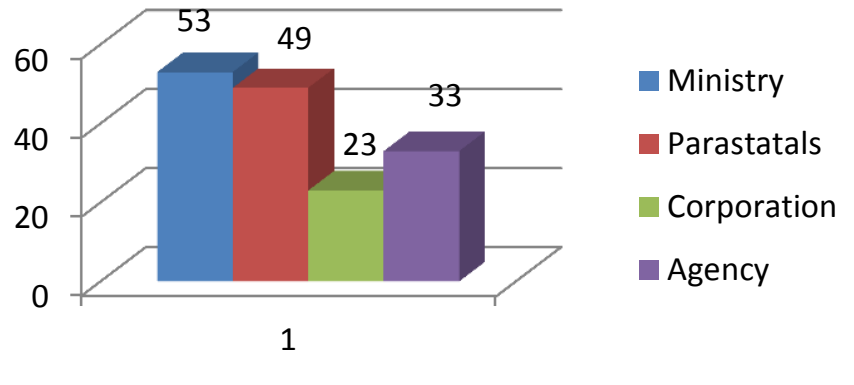


Table 5: Distribution Of Respondents By Length Of Service

\begin{tabular}{|l|l|l|l|l|l|}
\hline Column1 & $\mathbf{1}-\mathbf{5 y r s}$ & $\mathbf{6}-\mathbf{1 0}$ yrs & $\mathbf{1 1}-\mathbf{1 5 y r s}$ & above 15yrs & Total \\
\hline Frquency & 21 & 36 & 53 & 38 & 148 \\
\hline Percentage & 14.2 & 24.3 & 35.8 & 25.7 & 100 \\
\hline
\end{tabular}

From Table 5 and Figure 5 we observe that $35.8 \%$ of the respondents have being in their establishments for about 11 years to 15 years. $24.3 \%$ have been working for 6 to 10 years, $14.2 \%$ have in service for less than 5 years while $25.7 \%$ have been in service for more than 15 years.

All the analyses of the respondents point attention to the fact that the sample for this study is unbiased and normally distributed.

Figure 5: Bar Chart Showing the Length of Service of Respondents

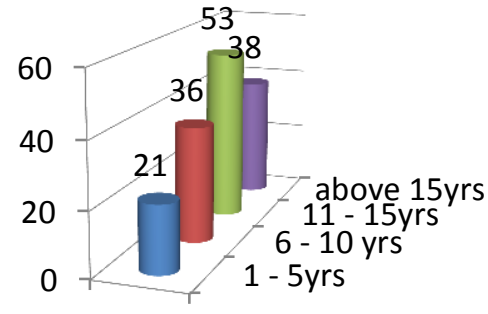

1
1 - $5 y$ rs

$6-10 \mathrm{yrs}$

$11-15 y r s$

above $15 y$ rs

\section{Section B: Descriptive Analysis Of Responses}

This section shows the analysis of all response in the questionnaire. If all respondents strongly agree to each item the highest score is 830 while if they all remain undecided the lowest score will be 166 .

Table 6: Presence Of External Control Institutions (Questions 1 to 6)

\begin{tabular}{|l|l|l|l|l|l|l|}
\hline ITEM & ESTABLISH & UNNECESSARY & FIGHT & OVERLAPPING & STREAMLINE & NOT FELT \\
\hline SCORE & 764 & 505 & 725 & 613 & 694 & 664 \\
\hline$\%$ & 92.05 & 60.84 & 87.35 & 73.86 & 83.61 & 80.00 \\
\hline
\end{tabular}

Figure 6:

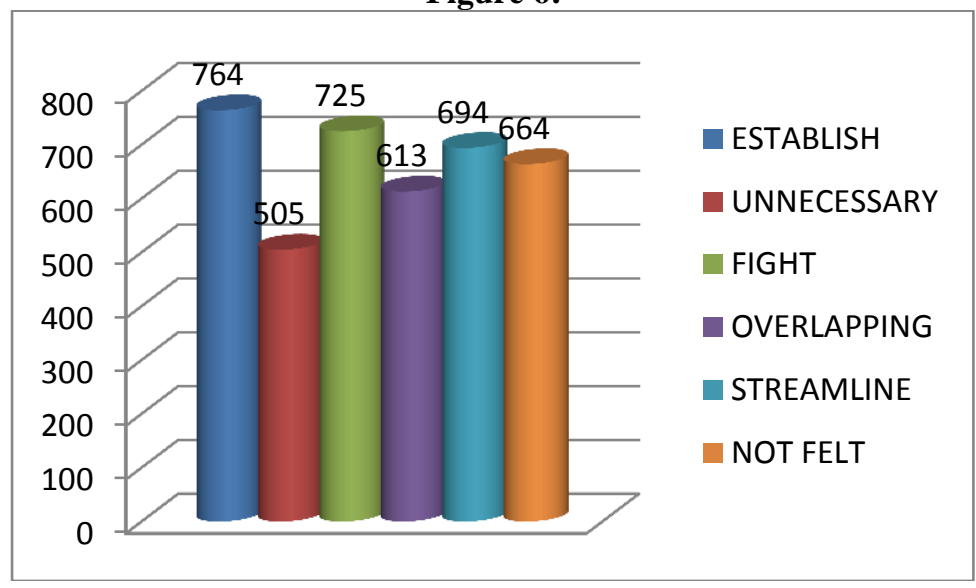

ESTABLISH $=$

UNNECESSARY =

government establish external control institution

establishment of external control institutions are unnecessary

the essence of these institutions is to fight against economic crimes.

OVERLAPPING =

STREAMLINE =

NOT FELT =

there is need to streamline these institutions to make them responsive.

the activities of these institutions are not felt on public fund management

Table 7: Operationalisation (QUESTION 7 - 11)

\begin{tabular}{|l|l|l|l|l|l|}
\hline ITEM & WEAK & STRENGTHEN & LAW & TOOTHLESS & FUNDING \\
\hline SCORE & 724 & 749 & 768 & 647 & 728 \\
\hline$\%$ & 87.23 & 90.24 & 92.53 & 77.95 & 87.71 \\
\hline
\end{tabular}


Figure 7:

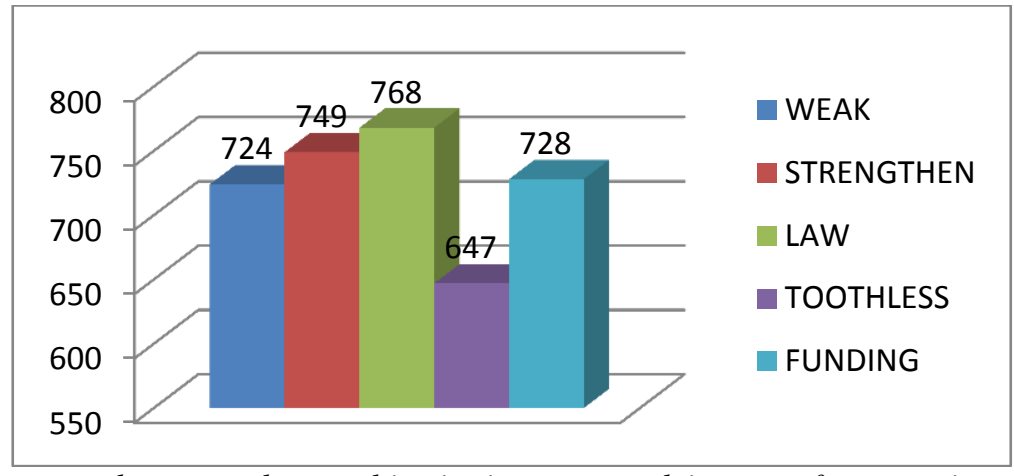

WEAK $=$

the external control institutions are weak in term of prosecuting economic crime offenders

STRENGTHEN = $\quad$ there is need to strengthen the law establishing these institutions to make them totally independent.

$L A W=$

there is need to strengthen Nigeria law enforcement and anti-corruption legislation

TOOTHLESS = external control institutions are best described as toothless backing dog

FUNDING = funding in terms of budgetary allocation is important to make the institutions independent of the executive

Table 8: Effectiveness (Questions 12 - 19)

\begin{tabular}{|l|l|l|l|l|l|l|l|l|}
\hline Item & Not Effective & Selfstyled & Failed & Corruption & Ineffective & Inadequate & Immunity & Functions \\
\hline Score & 621 & 696 & 676 & 735 & 724 & 587 & 675 & 603 \\
\hline$\%$ & 74.82 & 83.86 & 81.45 & 88.55 & 87.23 & 70.72 & 81.33 & 72.65 \\
\hline
\end{tabular}

Figure 8:

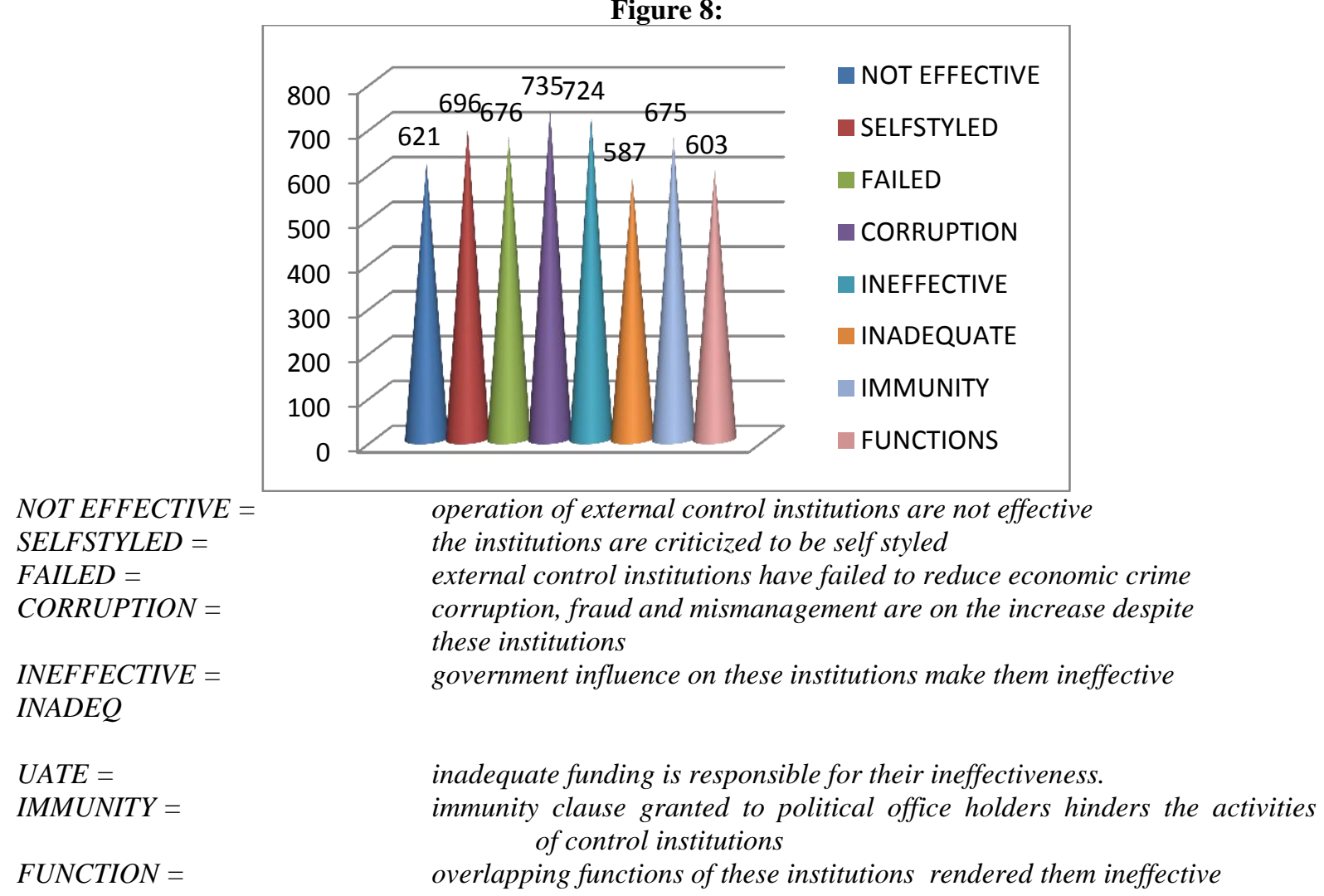


Table 9: Fund Management (Questions 20 -25)

\begin{tabular}{|l|l|l|l|l|l|l|}
\hline Item & Mismanage & Fraud & Civilservant & Weak & Lack & Political \\
\hline Score & 754 & 745 & 590 & 708 & 716 & 683 \\
\hline \% & 90.84 & 89.76 & 71.08 & 85.30 & 86.27 & 82.29 \\
\hline
\end{tabular}

Figure 9:

MISMANAGE = FRAUD = CIVILISERVANTS $=$ $W E A K=$ $L A C K=$

POLITICAL $=$

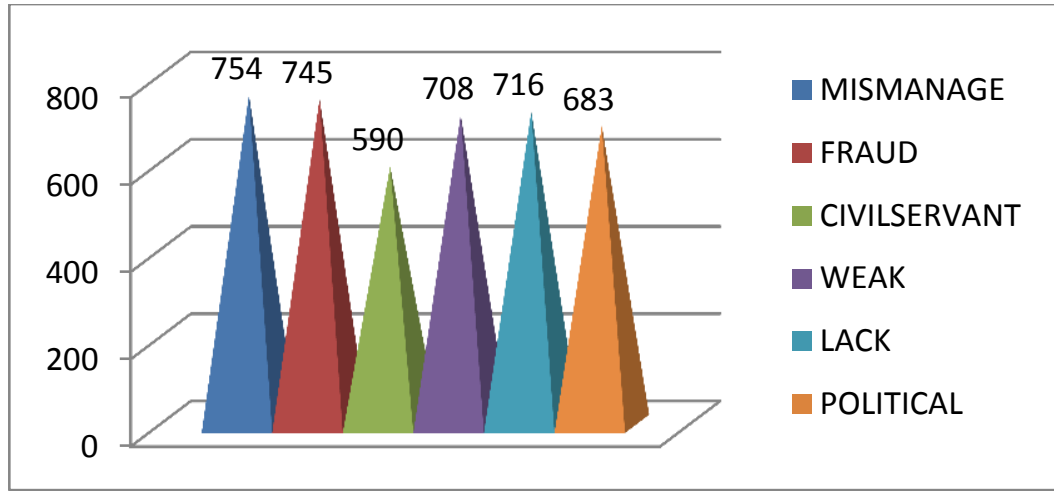

there is mismanagement of funds in our public sectors mismanagement of fraud is caused majorly by fraud and corruption the civil servants are the major cause of corruption and fraud external control on public funds management is weak there is lack of transparency and accountability in the management of our public fund mismanagement can be attributed to political office holders

\section{Empirical Analysis Of Responses}

\section{Effectiveness of External Control Institutions On Public Fund}

The empirical analysis here is to investigate the marginal impact of selected factors on the public fund management. The dependent variable is public fund management (PFMN). All responses in the questionnaire are categorized under three major factors which are: presence of external control, operationalisation and effectiveness, these are the set of independent variable. Data for this variable was generated as the pooled values of all responses under section B of the questionnaire. The study uses the method of Maximum Likelihood Censored Logistic Regression to analyze the relationship. This is because the scoring of the responses in the questionnaire follows the Likert rating of five scales. The relationship between public fund management and the set of independent variables is expressed in the following model

$$
P F M N=\beta_{0}+\beta_{1} P E C I+\beta_{2} \text { OPRTN }+\beta_{3} E F F E C T+\varepsilon \ldots . .(1)
$$

The result of the analysis is presented in Table 9. Table 9: Logistic Regression Results of Public Fund Management PFMN

Method: ML - Censored Logistic (Quadratic hill climbing)

\begin{tabular}{|l|l|l|l|l|}
\hline Variable & Coefficient & Std. Error & z-Statistic & Prob. \\
\hline PECI & 0.111364 & 0.06146 & 1.811957 & $0.07 * * *$ \\
\hline OPRTN & 0.395584 & 0.109005 & 3.629054 & $0.0003^{*}$ \\
\hline EFFECT & 0.10132 & 0.047092 & 2.15155 & $0.0314^{* *}$ \\
\hline C & 10.83904 & 1.984798 & 5.461031 & $0.0000^{*}$ \\
\hline & & & & \\
\hline Log likelihood & -381.5496 & & & \\
\hline SCALE:C(5) & 1.364754 & 0.087415 & 15.61227 & $0.0000^{*}$ \\
\hline
\end{tabular}

*significant at 1\%; **significant at 5\%; ***significant at $10 \%$.

The result in Table 9 shows that all the factors are positively related to the poor public fund management. The log likelihood is very low signifying that the three variables jointly impact the dependent variable. The coefficient of OPRTN and EFFECT are significant at $1 \%$ and $5 \%$ respectively, while the coefficients of PECI is significant at $10 \%$. The following inferences can be drawn from the results as regard the significant variables:

i. The presence of external control institutions increase rather than reduce mismanagement of public funds by about $11 \%$. 
ii. The weak operation of the external control institutions increase mismanagement of public funds in terms of frauds and corruption by about $39 \%$.

iii. The ineffectiveness of the external control institutions in terms of self styled, selective approach to investigation, dependence on the executive, increased mismanagement of public funds by about $10 \%$.

Other inferences from the descriptive analysis are

i. Government established external control institution but their operations have ineffective as regard economic crime.

ii. There is need to strengthen Nigeria law enforcement and anti-corruption legislation to make external control independent of the executive.

iii. Corruption, fraud and mismanagement are on the increase despite these institutions.

iv. There is mismanagement of funds in our public sectors identified by fraud and corruption in Nigeria.

\section{Conclusion}

It is rather unfortunate that the level of transparency and accountability experienced in Nigeria is below acceptability. This is simply due to weak accounting system, ineffective external control and the cogs in the wheel of our legal framework. The fight against corruption and fraud in Nigeria need real patriots, men and women who are duly committed to the Nigerian project and not immoral personalities who want to serve their own or narrow group interests. It takes high moral rectitude to exercise the moral strength required to be an anticorruption crusader in this country. In the light of this, there is a need for a sustained public enlightment campaign about the right and duties of the entire individuals under the law. Persons convicted of corruption should be disqualified from holding public offices and or disenfranchise from partaking in politics.

The culture of celebrating convicted persons should be discouraged. Integrity must be encouraged, practiced and enforced. Law enforcement and anti-corruption legislation must be strengthened. Besides, funding to anticorruption institutions should be autonomous and charged directly to consolidated revenue fund to enshrine their independency.

\section{References}

[1]. Akanbi, M. (2005) Corruption and challenges of good Governance in Nigeria in Lai Olurode and Remi Anifowose (eds) Rich but Poor, Corruption and Good Governance in Nigeria, Lagos.

[2]. Aransi, I. O (2008) Bureaucratic Corruption in the public service. A case study of the Nigerian local Government in Adeyemo D. O. And Olojede, I.

[3]. Otite, O. (1986) On the Sociological study of corruption in Femi Adekunle (ed) Corruption in development, Ibadan, University press.

[4]. Sahara Africa (2002) Corruption Denied the ordinary citizen the basic means of livelihood.

[5]. Shehu, A.Y (2004) Combating corruption in Nigeria: Bliss or Bluster?, Journal of

[6]. financial crime, $12(1): 69-87$

[7]. The Guardian (2012) Efcc arrests ondo state osopadec chair over N61.63b Fraud

[8]. Transparency International, Global corruption Barometer, 2010.

[9]. (www.ataransparency.org)

[10]. Jump up (2012) Corruption perception index Transparency International 